Q.630.7

I $\ell 6 \mathrm{C}$

no. 1307 



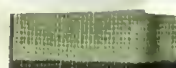
$m^{2}$ 
Alternatives in Insect Management

\section{Field and Forage Crops}

$\begin{array}{lrlr}\text { Field Crops, Insects, and } & & \text { Trap Crops } & 16 \\ \quad \text { Insecticides in Illinois } & \mathbf{1} & \text { Reduced Tillage } & 17 \\ \text { Illinois Field Crops } & 2 & \text { Cover Crops } & 18 \\ \text { Major Field Crop Pests } & 2 & \text { Intercropping } & 18 \\ \text { Insecticide Use } & 2 & & \\ & & \text { Controlling Pest Infestations } & 21 \\ \text { Production Practices and } & & \text { Monitoring Pest Populations } & 21 \\ \quad \text { Insect Pest Management } & 2 & \text { Thresholds for Control } & 22 \\ \text { Crop Rotation } & 6 & \text { Selecting Alternative and } & \\ \text { Resistant Varieties } & 9 & \text { Conventional Control Methods } & 22 \\ \text { Altering Planting or Harvesting Dates } & 13 & \text { Summary } & 24\end{array}$

SYNTHETIC INSECTICIDES play an essential role in agriculture today. Yet regulatory actions, concerns about the environment and human health, and the high costs of some insecticides are encouraging researchers and farmers to seek alternative methods of insect control. To meet the needs of agriculture and society, those alternatives must be practical, effective, and economical; they also should provide environmental and human health advantages in comparison with currently used insecticides.

This circular examines the pest management impacts of crop production practices specifically intended to provide pest management alternatives or to reduce erosion, enhance fertility, or provide other benefits. Such practices include rotating crops, planting resistant varieties, manipulating planting or harvesting dates, and using trap crops. The pest management consequences of reduced tillage, cover crops, and intercropping are also discussed. We include pest-specific recommendations, references on scouting and economic thresholds, and suggestions for choosing the most appropriate control practices when pest outbreaks occur.

The efficacy of many of the practices mentioned here have been recognized for many years; how- ever, the low cost of the highly effective synthetic insecticides first produced in the 1940s and 1950s allowed the development of crop production systems that are less reliant on agronomic practices intended to reduce pest problems. Changing attitudes about the use of pesticides and increased knowledge of the ecology of pest management now provide a new context for judging these "old" alternatives.

Chapter 1 of the 1991 Illinois Pest Control Handbook, "Insect Pest Management for Field and Forage Crops," contains guidelines for monitoring insect infestations, presents thresholds, and lists insecticides registered for specific crop-pest combinations. Another useful reference for the management of field crop pests is the Field Crop Scouting Manual (Curran et al. 1990).

\section{FIELD CROPS, INSECTS, AND INSECTICIDES IN ILLINOIS}

Evaluating alternatives for the management of field crop pests requires an understanding of current problems and practices. A review of information on major crops, major insect pests, and insecticide use provides a starting point for that understanding.
Prepared by T. Henn, R. Weinzierl, M. Gray, and K. Steffey Office of Agricultural Entomology, University of Illinois at Urbana-Champaign, College of Agriculture, Cooperative Extension Service, in cooperation with the Illinois Natural History Survey
AGAIGULTURE LIBRARY

MAY 011991

Circular 1307

February 1991 


\section{Illinois Field Crops}

In 1988, field crops were grown on about 26 million acres of Illinois cropland (Pike et al. 1990). Most of that acreage produced corn and soybeans (39 percent and 35 percent of the total, respectively); smaller but substantial portions of the state's crop acreage were used to raise wheat (5 percent) and alfalfa ( 3 percent). Sorghum, oats, clover, hay, and pasture together accounted for another 6 percent of the state's field crop acreage, and the remaining 12 percent was held out of production in "set-aside" acreage, a part of the federal farm program intended mainly to prevent overproduction of certain commodities. This publication centers on the four major field crops in Illinois: corn, soybeans, wheat, and alfalfa.

\section{Major Field Crop Pests}

Many insects infest field crops in Illinois. Although several species cause significant damage in sporadic outbreaks, only a few species consistently cause enough damage to be considered major pests. Designing management programs for these pests requires at least a general knowledge of their life cycles and the damage they cause. Table 1 summarizes that information. Although this chapter concentrates on the major pests listed in Table 1, information on less important pests is included where appropriate.

\section{Insecticide Use}

Existing patterns of insecticide use must be understood before alternatives can be considered. Table 2, adapted from Pesticide Use in Illinois: Results of a 1988 Survey of Major Crops (Pike et al. 1990), provides data useful for developing that understanding. Important observations from Table 2 include the following:

- Approximately 30 percent of all corn acreage was treated with a soil insecticide in 1988. Most of these treatments (22 percent of the total corn acreage) were applied to control corn rootworms.

- Post-emergence insecticides were used on approximately 6 percent of all corn acreage in 1988. Because a severe drought occurred in 1988, post-emergence insecticide use differed somewhat from normal. With average rainfall, more acres are likely to be treated to control European corn borer (about 5 percent for first and second generations combined; treating even more acres is economically justified in some seasons), and fewer acres are likely to be treated for spider mites or corn rootworm beetles, pests that were more numerous or more damaging because of dry conditions in 1988.

- About 40 percent of the state's 9 million acres of soybeans received an insecticide/miticide application to control spider mites in 1988. Except when drought favors spider mite outbreaks, less than 1 percent of the state's soybeans are treated for spider mites. Bean leaf beetles, like spider mites, are seldom of economic importance. Although about 5 percent of the soybean acreage was treated in 1988, less than 1 percent received an insecticide application for this pest in any other year during the 1980s.

- Although only 7 percent of the state's alfalfa acreage was treated for alfalfa weevil or potato leafhopper in 1988, insecticides commonly are used on 10 to 35 percent of the Illinois alfalfa crop for alfalfa weevil control; 5 to 15 percent of the crop is treated for leafhopper control. Alfalfa weevil infestations are typically greatest in the southwestern portion of the state.

Table 2 clearly indicates that the majority of the state's field crop acreage is not treated with any insecticide. (The situation differs in fruits and vegetables where cosmetic standards dictate greater use of insecticides and fungicides. In addition, nearly 100 percent of the state's corn and soybean acreage is treated with one or more herbicides each year.) Although insecticides are not used in all fields, opportunities to reduce insecticide use do exist.

\section{PRODUCTION PRACTICES AND INSECT PEST MANAGEMENT}

Farming practices ("cultural practices") influence pest populations. Crop rotation, planting different crops in a field in successive years instead of planting the same crop every year, disrupts the life cycles of some major insect pests; it also contributes to weed control. Other cultural practices that are important in the management of insect pests include planting resistant varieties, following planting or harvesting schedules that avoid peak periods of pest attack, and using trap crops. Tillage practices, cover crops, and intercropping also produce important impacts on pest populations. 
Table 1. Major Field Crop Pests in Illinois

\begin{tabular}{|c|c|c|c|c|}
\hline $\begin{array}{l}\text { Crop and } \\
\text { pest }\end{array}$ & $\begin{array}{l}\text { Damaging } \\
\text { stage }\end{array}$ & Type of damage & $\begin{array}{l}\text { Genera- } \\
\text { tions } \\
\text { per year }\end{array}$ & Overwintering stage \\
\hline
\end{tabular}

\section{CORN}

Northern and

\begin{abstract}
western corn
\end{abstract}
rootworms

Larva

Feed on corn roots, causing physiological stress, lodging, and reduced yields.

Adult Feed on corn silks, causing reduced pollination and poorly filled ears.

Wireworms Larva

White grubs

Larva

Black cutworm

Larva

European corn

Larva

borer

Corn leaf aphid

Nymph and adult
Feeds on germinating seeds or seedling stems below the soil surface; may kill plants, reducing stands. Infestations often scattered, spotty.

Feeds on roots of seedlings, causing them to wilt or die, reducing stands. Infestations often scattered, spotty.

Feeds on foliage or cuts off young seedlings at soil level.

First generation feeds on foliage and bores into stem of whorl-stage plants, causing physiological stress. Secondgeneration larva tunnels into ears, ear shanks, and stems near the tassel, causing breakage, lodging, and ear drop. Tunneling in stalk also reduces yield.

Can build to high numbers in the whorl at tasseling. Aphids suck plant sap, causing wilting. Honeydew can lead to sooty molds, poor pollination, and undersized kernels.

Greatest damage in dry years.
$<1$ Larva or pupa, in soil.

$<1$ Larva, in soil.

3

Migrates into Illinois from south each spring.

2 to 3 Mature larva, in corn stubble.
Many Migrates into Illinois from south each summer.

\section{SOYBEANS}

Bean leaf beetle

Adult

$\begin{array}{ll}\text { Grass- } & \text { Nymph and } \\ \text { hoppers } & \text { adult }\end{array}$

Feeds on cotyledons and stems of seedlings, sometimes reducing stands. Later generations feed on foliage and pods. Pod feeding can contribute

Feed on all above-ground plant parts. Usually moves into fields from roadsides and noncrop areas late in the season. 
Table 1. (cont.)

\begin{tabular}{lllll}
\hline $\begin{array}{l}\text { Crop and } \\
\text { pest }\end{array}$ & $\begin{array}{l}\text { Damaging } \\
\text { stage }\end{array}$ & Type of damage & $\begin{array}{l}\text { Genera- } \\
\text { tions } \\
\text { per year }\end{array}$ & Overwintering stage \\
\hline $\begin{array}{l}\text { Soybeans (cont.) } \\
\text { Twospotted } \\
\text { spider mite }\end{array}$ & $\begin{array}{l}\text { Nymph and } \\
\text { adult }\end{array}$ & $\begin{array}{l}\text { Sucks plant cell contents, } \\
\text { reducing photosynthetic } \\
\text { capacity. Yellowing and } \\
\text { browning of leaves is followed } \\
\text { by wilting. Seldom damaging } \\
\text { except in unusually dry } \\
\text { seasons. }\end{array}$ & Many & $\begin{array}{l}\text { Females, in vegetation (roadsides, } \\
\text { waterways, and noncrop areas). }\end{array}$ \\
\hline
\end{tabular}

\section{WHEAT}

Hessian fly

Larva

Larva
Armyworm

Larva and adult

$\begin{array}{ll}\text { ALFALFA } & \text { Larva and } \\ \text { Alfalfa weevil } & \text { adult }\end{array}$

Potato leafhopper
Nymph and adult
Consumes plant foliage and sometimes feeds on ripening heads. Occasional pest that infrequently causes economically important damage.

Feeds between leaf sheath and stem. May kill the plant by destroying the growing tip; interfere with tillering; cause lodging, stunting, reduced weight, or winter kill; or lead to fungal infections.
2 to 3 Mature larvae, in soil.

2

Mature larva, in "flaxseed" puparium on the wheat stem.
Larva feeds on the new buds and young foliage; adult skeletonizes foliage and sometimes feeds on regrowth after the first cutting. Extensive damage reduces yield and quality of hay.

Sucks plant sap causing Vshaped yellowing of leaf tips and general wilting. Chemical changes in response to feeding cause reduced protein and elevated sugar content, stunting, and overall reduced yield.
1

Egg or adult in alfalfa stems and crowns.

3 to 4

Migrates into Illinois from south each summer. 
Table 2. Insecticide Use on Illinois Corn, Soybeans, and Alfalfa in 1988

Approximate

$\%$ of crop

Crop Acres grown Target pest Acres treated treated

\section{SOIL INSECTICIDES}

\begin{tabular}{|c|c|c|c|c|}
\hline \multirow[t]{4}{*}{ Corn } & $10,041,000$ & Corn rootworms & $2,200,000$ & $22 \%$ \\
\hline & & Wireworms & 400,000 & $4 \%$ \\
\hline & & Cutworms & $\underline{400,000}$ & $4 \%$ \\
\hline & & & $3,000,000$ & $30 \%$ \\
\hline
\end{tabular}

\section{POSTEMERGENCE INSECTICIDES}

Corn

$10,041,000$

Cutworms

130,000

72,000

$1.3 \%$

First-generation European corn borers

Second-generation European corn borers

3,000

$0.7 \%$

Corn rootworm beetles

326,000

$<0.1 \%$

Spider mites

50,000

581,000

$3.4 \%$

$\frac{0.5 \%}{6.0 \%}$

Soybeans

$9,089,000$

Bean leaf beetle

460,860

$\underline{3,600,000}$

$4,060,860$

$5.0 \%$

Spider mites

$\underline{39.6 \%}$

$44.6 \%$

$\begin{array}{lll}\text { Alfalfa } & 691,000 & \text { Alfalfa weevil } \\ & \text { Potato leafhopper }\end{array}$

\begin{tabular}{rr}
46,000 & $6.7 \%$ \\
1,900 & $0.3 \%$ \\
\hline 47,900 & $7.0 \%$
\end{tabular}

SOURCE: From Pike et al. (1990).

See text (page 2) for discussion of unusual treatment practices resulting from the 1988 drought. Widespread treatment of soybeans for spider mite and bean leaf beetle control is not common under normal precipitation. 


\section{Crop Rotation}

Benefits of Crop Rotation. Crop rotations minimize problems with weeds, diseases, nematodes, and insects that thrive only in certain crops. Crop rotations aid in weed control because they allow a farmer to use different cultivation practices and different herbicides so that weeds that are difficult to control in one crop can be controlled by different methods in another. Rotations are especially important for managing crop diseases because many pathogens decline in density during the years when nonhost crops are grown. Certain rotations, especially those including legumes, build or maintain soil structure or fertility.

Although rotating crops provides many benefits, it does not affect all insects equally. Insects most susceptible to control by crop rotation are soil-dwelling pests that are crop-specific and relatively nonmobile (at least in the larval stage that causes the most damage). Of those, the species most affected by rotation overwinter in the soil as eggs or partially grown larvae. Rotating to a different crop removes the pest's food source, and the pest dies of starvation when it becomes active in the spring.

Crop rotation does not control insects that migrate into Illinois from the south each spring (for example, black cutworm, armyworm, and potato leafhopper). Rotation is also ineffective against highly mobile insects that overwinter in Illinois as adults, pupae, or fully mature larvae that pupate and emerge as mobile adults in the spring (European corn borer and bean leaf beetle, for example). Adults of these insects deposit their eggs in suitable crops in the spring and early summer, and the subsequent generation damages the crop during the same season.

While crop rotation does not control most of the insect pests of Illinois field crops, it does control two extremely important pests, the northern and western corn rootworms. As larvae, these insects feed only the roots of corn. The eggs are laid in soil at the base of corn plants in late summer, and they hatch the following spring (see Figure 1). If corn is present again in the same field, the larvae feed on and may cause serious damage to the

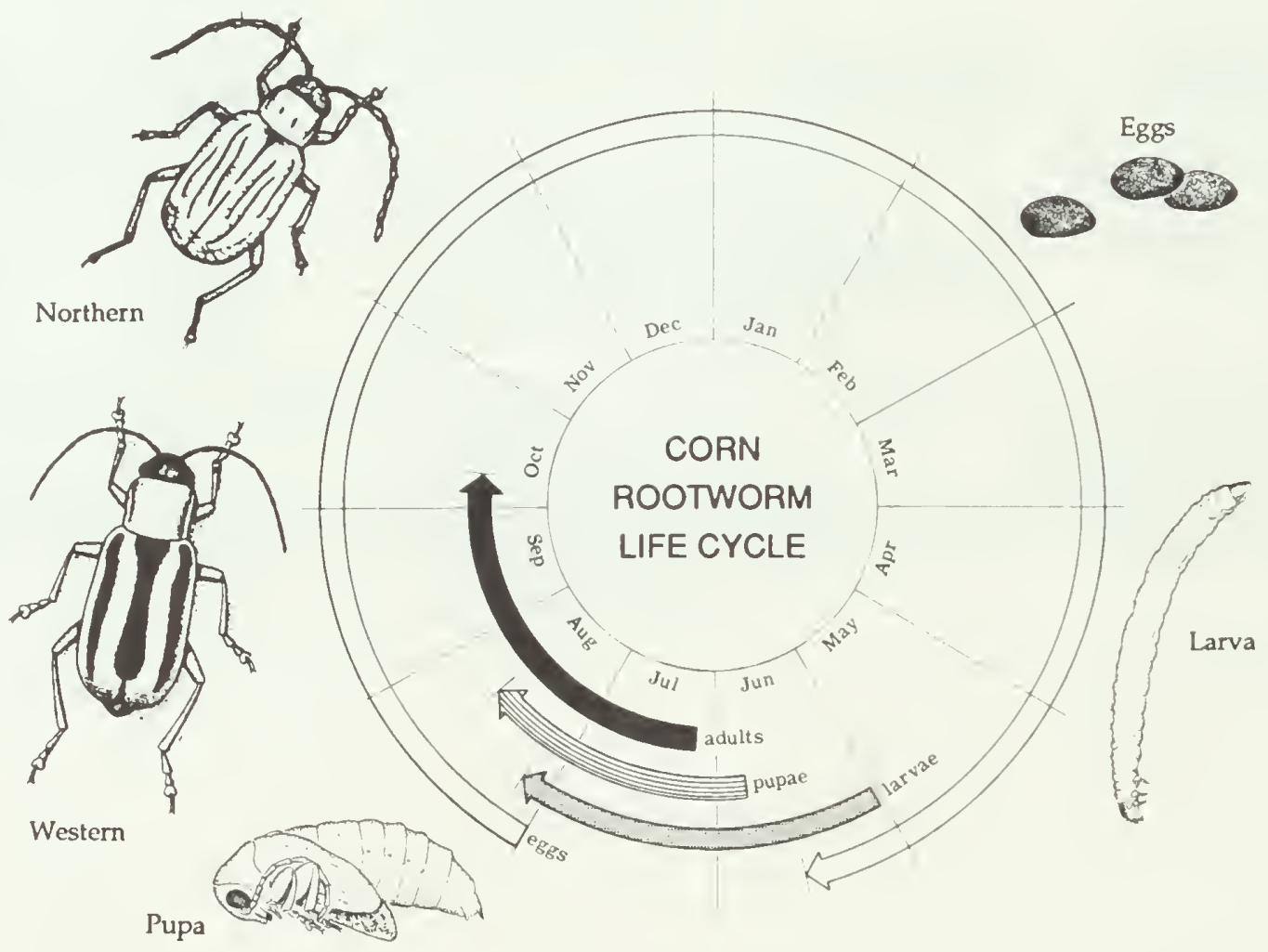

Figure 1. Life cycle of western and northern corn rootworms. Eggs deposited in cornfields in August and September overwinter and hatch in late May and early June. Larvae feed on corn roots in June and July before pupating. Adult beetles are active in late July, August, and September. (Illustration adapted from Publ. E-201, Purdue University, West Lafayette, Indiana.) 
root system. If another crop such as soybeans is present, the larvae die of starvation soon after hatching because they are unable to disperse from the field to locate a corn crop.

Patterns of insecticide use (from Pike et al. 1990) illustrate the importance of crop rotation in managing corn rootworms. In 1988, 26 percent of Illinois' corn crop was grown in fields that had produced corn in 1987 (corn after corn); 66 percent was corn after soybeans, and the remaining 8 percent was corn after wheat, alfalfa, or other crops. Of the corn-after-corn acreage, 83 percent (over 2 million acres) was treated with a soil insecticide at planting, primarily for corn rootworm control. Only 14 percent of the corn after soybeans and 29 percent of the corn after other crops were treated with a soil insecticide at planting, primarily to control cutworms, wireworms, or white grubs.

Any rotation that avoids producing corn in the same field in successive years prevents economically important damage from corn rootworms in Illinois. This benefit remains true even though researchers have observed that a portion of the eggs of the northern corn rootworm can remain dormant for more than one winter. When this phenomenon (called extended diapause) occurs, larvae hatch one or two years later than normal, sometimes in fields where corn has again been planted following other rotation crops. Although northern corn rootworms can cause some damage to corn when extended diapause occurs, only very rarely have infestations resulted in economic damage to corn planted in rotation with any other crop in Illinois. Crop rotation remains effective for corn rootworm control in Illinois despite the infrequent occurrence of extended diapause in the northern corn rootworm.

Other Illinois insects managed in part by rotation are corn billbugs in corn, grape colaspis in soybeans, and the Hessian fly in wheat. However, because billbugs and grape colaspis seldom occur at damaging levels, and because rotations offer only limited control of the Hessian fly, these pests are rarely considered in crop rotation plans.

Problems Associated with Crop Rotations. Not all crop rotations reduce the densities of important pests. Some species of wireworms and white grubs are favored by rotations that include grasses, perennial legumes, or set-aside acreage, especially if weed growth is uncontrolled. These pests often cause economic damage by feeding on the seedlings and roots of corn planted in rotation after grass pastures and set-aside acreage.

In summer months, adult wireworms and white grubs (beetles shown in Figures 2 and 3) deposit their eggs mostly in grasses, perennial legumes, or uncultivated areas. Larvae of common species feed in the soil for three to five years, a period during which several crops may be grown in a single field. Wireworm larvae feed below the soil surface on seeds and on the underground stems and roots of many plants, including corn. White grubs also feed on the roots and underground stems of a range of plants. Despite their general feeding habits, wireworms and white grubs rarely cause economic damage to crops other than corn in Illinois.

Crop rotations that alternate corn and soybeans generally experience the fewest problems with wireworms and white grubs. These pests are more common in corn planted in more complex rotations that include small grains, pasture grasses, and legumes, at least in part because these crops are more attractive to egg-laying beetles. Consequently, scouting for wireworms and white grubs is especially important where corn is to be planted in fields formerly used for pastures, legumes, or setaside acreage.

Because crop rotations provide benefits other than insect control (building soil structure and fertility and contributing to weed and disease management, for example), producers may elect to design a generally favorable crop rotation and then deal with subsequent insect problems as effectively as possible. The probable impacts of common IIlinois crop rotations on pest insects are presented in Table 3.

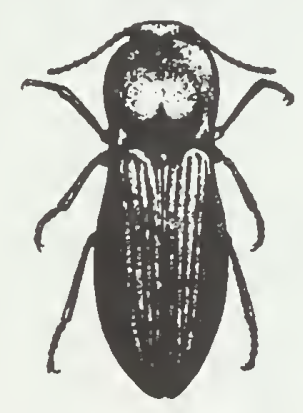

Adult

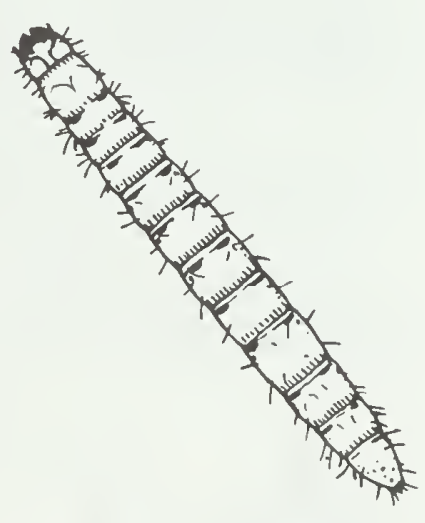

Larvae
Figure 2. Wireworm adult and larva. Adult beetles deposit eggs in grasses, perennial legumes, and noncrop areas in the summer. Larvae feed on underground parts of plants including corn seeds and seedlings. Larvae feed for 3 to 5 years before maturing to the adult stage. (Illustration adapted from Extension Circular E-188, North Dakota State University, Fargo.) 
Table 3. Effects of Crop Rotations on Insect Pests

\begin{tabular}{|c|c|c|}
\hline Rotation & Insects managed & Problem insects \\
\hline Continuous corn & $\begin{array}{l}\text { Wireworms and white grubs are } \\
\text { usually less problematic because } \\
\text { of control by soil insecticides } \\
\text { applied for corn rootworms and } \\
\text { because adults prefer to deposit } \\
\text { eggs in other crops. }\end{array}$ & $\begin{array}{l}\text { Western and northern corn } \\
\text { rootworms frequently occur } \\
\text { at damaging population } \\
\text { levels whenever corn } \\
\text { follows corn. This problem } \\
\text { outweighs other rotation } \\
\text { effects on pest insects. }\end{array}$ \\
\hline
\end{tabular}

Corn after soybeans

Corn after wheat

Corn after alfalfa (or clover or other hay)

Corn after sod or set-aside

Continuous

soybeans

Continuous

wheat
Western and northern corn rootworms are managed by any rotation that disrupts continuous corn. Wireworms and white grubs usually do not build up to damaging levels in a cornsoybean rotation. Avoiding continuous soybeans reduces the prevalence of grape colaspis.

Western and northern corn rootworms are managed by any rotation that disrupts continuous corn.

Western and northern corn rootworms are managed by any rotation that disrupts continuous corn.

Western and northern corn rootworms are managed by any rotation that disrupts continuous corn.

None

None
Black cutworms may be slightly more prevalent in corn after soybeans than in continuous corn, but the effects of rotation are secondary to weediness at the time moths deposit eggs. (Weedy fields in March and April are most likely to suffer cutworm damage later.)

Armyworms, wireworms, and white grubs may infest wheat and subsequently become economically damaging to corn, especially under reduced tillage.

Wireworms and cutworms are more common (but still sporadic) after legumes and other perennial crops. Grape colaspis may become economically damaging to corn after red clover.

Wireworms, white grubs, corn billbugs, cutworms, armyworms, and sod webworms are more common.

Grape colaspis, as well as diseases and nematodes, are favored by continuous production of soybeans.

Hessian fly infestations may build up if fly-free dates are not observed and resistant varieties are not used. Armyworms may become more damaging.
Additional notes

Black cutworm moths lay eggs less often in corn stubble than in soybean or wheat stubble. The likelihood of cutworm problems is therefore slightly reduced in continuous corn.

Most soybean pests are not influenced by rotation with corn.
Diseases that persist from season to season generally prevent continuous wheat production. 
Constraints on Rotations. Although crop rotation usually provides substantial benefits, some rotations are not economically or ecologically desirable in all areas. The rotations that work at specific locations depend on soil type, land contours, climate (length of growing season, severity of winters, etc.), the nature of farm operations, and participation in federally sponsored farm programs. For example, most of the continuous corn in Illinois is grown in the northwest portion of the state where rolling lands are highly erodible. Rotating corn with soybeans is undesirable there because soybean stubble does not prevent the erosion of soil by running water as effectively as corn stubble. Although the use of winter cover crops might help to hold the soil after soybean harvest, establishing a cover crop before winter is not always possible in this region. In addition, many farmers in northwestern Illinois raise hogs or cattle and may require supplies of corn (for feed) that can be met most economically by raising corn on the majority of their acreage. While planting corn after corn favors certain insects and crop diseases, it may be the most economical practice (at least in the short term) on these farms, despite the fact that fertilizer and insecticide inputs are usually relatively high.

Federally sponsored farm programs also interfere with crop rotations in some instances. These programs attempt to optimize production and marketing by subsidizing the production of certain commodities and by paying farmers to set aside some acreage. Because farm program benefits vary according to the acreage "base" that a farmer has devoted to corn production (or the production of certain other crops), planting at least some corn after corn without rotation has led to an increase in farm program payments in some cases. Because federal farm programs have become extremely
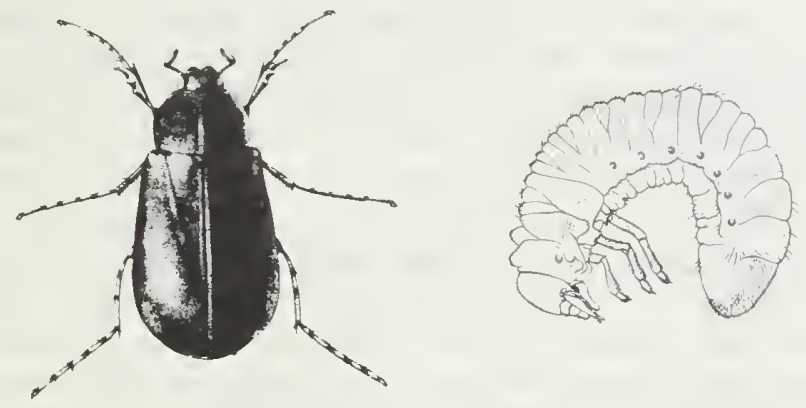

complex, their influence on crop rotations and insect management represents only a minor portion of their overall impacts on farming. Nonetheless, any changes in farm programs that encourage or allow optimum use of crop rotations for pest management should be considered as important improvements.

\section{Resistant Varieties}

Through evolution, many plants have developed defenses against diseases, insects, and larger planteating animals. They may produce repellent or toxic chemicals; possess thorns, hairs, or tough tissues that act as physical barriers; or have growth habits that protect them from attack or help them to recover. These traits are all determined genetically.

During the process of breeding crops for high yield and food quality, some protective or defensive traits present in wild or more primitive species or strains have been enhanced; others have been lost. When traits that provide insect resistance have been the objects of breeding programs, specific resistant varieties have resulted (see Tables 4 and 5). In other instances, overall plant vigor or at least some level of resistance to common pests allows commercial varieties to withstand moderate infestations even though specific breeding programs have not targeted every pest species (for example, corn root regrowth following rootworm damage, the "standability" and yield of current corn varieties when infested by European corn borer, and the ability of soybean varicties to yield well despite substantial defoliation).

Conversely, defensive traits can be "bred out" as a result of breeders' efforts to select otherwise superior varieties. The loss of defensive traits can occur inadvertently when insecticides are used to prevent insect damage during selective breeding
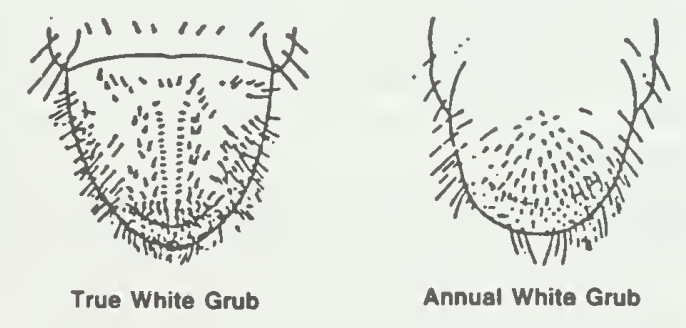

Figure 3. White grub adult and larva. The last abdominal segment of perennial white grubs ("true" white grubs) bears bristles arranged in a zipperlike pattern; the corresponsing bristles on annual white grubs are not arranged in such a pattern. Although annual white grubs cause little or no damage in field crops, perennial white grubs can cause economic losses. (Illustrations adapted from Bulletin 773, Agricultural Experiment Station, University of Illinois at Urbana-Champaign and from MP 517, University of Missouri, Columbia.) 
programs. Where insecticides are used during variety development, the selection process cannot identify improvements or losses of insect resistance. The unintentional selection of susceptible varieties can result in part from plants using limited resources in their growth and reproduction; energy and nutrients used for defense may reduce the resources available for yield. In contrast, varieties that produce higher yields may do so by reducing the resources allocated to certain defense mechanisms.

Variety development programs may even reduce resistance mechanisms intentionally. Although a current example of crop improvement involves an endophytic fungus (a fungus that lives within a plant) instead of a crop-produced compound, it illustrates the underlying issue. Tall fescue, a widely used pasture grass, is commonly infected by a seed-borne fungus (an endophyte) that produces antibiotic compounds that interfere with the development of insects, thereby providing at least some degree of insect resistance to the infected fescue. But these fungus-produced chemicals are also toxic to cattle and other mammals. Cattle that feed on endophyte-infected fescue often lose weight or gain weight at rates substantially lower than normal. Severe injuries and death can occur when animals consume large amounts of the fungus in infected grass. As a result, cattle producers are attempting to establish endophyte-free stands of fescue to improve cattle performance. (Simultaneously, the grass seed industry is marketing endophyteinfected seed to provide insect resistance in home lawns.) The key concern in this and similar situations is that resistance mechanisms that depend on the production of chemical substances toxic to invertebrate and vertebrate animals alike limit the feed or food value of the crop plant. Selecting varieties less resistant to pests but more nutritious to livestock and humans can involve targeting the same plant chemical.

Types of Resistance. Crop resistance to insects can be characterized in several ways. It may be physical, resulting from the toughness of tissues, the thickness of stems, roots, or other structures, or the kinds and degree of pubescence (hairiness); chemical, resulting from the production of any of a wide array of compounds that repel, deter, weaken, or kill insects that attempt to feed; or phenological, resulting from the timing of crop development so that the presence of the susceptible stage of the plant does not coincide with the attacking stage of the insect. Resistance can also be categorized by the nature of the plant-pest interaction. Resistance can result from antixenosis (anti meaning "against" and xenos meaning "stranger"), in which plant features discourage certain insects from initially infesting the crop; this type of resistance is also called nonpreference. Antibiosis (anti meaning "against" and bios meaning "life") refers to mechanisms that involve chemical defenses that kill the insect or prevent it from developing properly after it begins feeding. Tolerance, the ability to withstand infestation and feeding damage without yield reduction, is also a form of resistance. Resistance mechanisms are mentioned briefly in Table 4 along with other information on resistant varieties.

Benefits and Drawbacks of Resistant Varieties. Most farmers in lllinois choose crop varieties primarily according to their yield potential and the time required to reach maturity ("shorter season" varieties for cooler climates of northern areas). Although resistance to pathogens (for example, cereal rusts and the soybean cyst nematode) may determine the selection of a particular variety, only rarely is resistance to insects considered. Even so, planting resistant varieties where they are available and productive offers many benefits. Insect resistance does not interfere with other pest management practices such as tillage or the application of insecticides. These tactics remain effective and do not compromise the benefits provided by resistance. In some instances, resistance may slow insect development or population increase so that other management practices (for example, cultural controls, action of beneficial insects, and planting or harvesting dates) become more effective and/or insecticides can be used less frequently or at reduced rates. Also, there is generally little or no added cost involved in growing a resistant variety.

For a number of reasons, insect resistance (like insecticides) is not a complete and simple answer to every pest problem. Many resistance factors convey resistance to only one species of insect. Efforts to use such factors in the development of commercial varieties must avoid the inadvertent development of a variety with increased susceptibility to other insects or diseases, and additional pest management tactics must be used to deal with other pests that attack the resulting variety. Varieties resistant to a certain pest sometimes yield less than susceptible varieties when infestations of that pest do not develop. Lower yields may occur because plants devote resources to resistance mechanisms (not yield) that provide no benefit in the absence of the pest. Of course, the same resistance mechanisms allow the plant to survive and produce a crop with reduced pesticide costs when the pest is present. The payoff of resistant varieties, therefore, is greatest when the target pest occurs in most 
Table 4. Insects Managed by the Use of Resistant Crop Varieties

\begin{tabular}{lll} 
Crop & Insect & Nature of resistance \\
\hline Corn & European corn borer & $\begin{array}{l}\text { Screening trials conducted by seed companies since the 1960s have } \\
\text { selected varieties less susceptible to infestation, stalk breakage, and yield } \\
\text { reduction. Resistance factors have not always been identified. In some } \\
\text { varieties, high levels of DIMBOA and other factors in young corn plants } \\
\text { cause mortality of first-generation corn borers. Other unidentified factors } \\
\text { cause reduced tunneling by second-generation borers. }\end{array}$
\end{tabular}

Corn rootworms

Soybean Potato leafhopper

Spider mites

Bean leaf beetle and Mexican bean beetle

Wheat Hessian fly

Alfalfa

Aphids (spotted alfalfa aphid, pea aphid, blue alfalfa aphid)

Potato leafhopper

Alfalfa weevil
Varieties with larger root masses and greater compensatory regrowth of roots show some tolerance in the form of greater "standability" or reduced lodging. Data on varietal differences in rooting habits or rootworm resistance are not available.

Hairiness (pubescence) of stems, leaves, and pods deters feeding by potato leafhoppers.

In variety trials conducted in 1988 (during a severe outbreak of the twospotted spider mite), the variety Burlison was the least damaged. The source of its possible resistance or tolerance has not been identified; its performance under rigorous screening for resistance to spider mites has not been evaluated.

Hairiness may deter pod-feeding beetles. An experimental Maturity Group III germ line resistant to foliage feeders in general (bean leaf beetle, Mexican bean beetle, and others) has been identified in breeding programs at Purdue University. This germ line is low yielding, and resistance factors have not yet been incorporated into agronomically acceptable commercial varieties.

Although 20 different resistance genes have been identified, only 5 have been deployed in commercial varieties. Resistance genes $\mathrm{H} 7-\mathrm{H} 8, \mathrm{H} 3, \mathrm{H} 5$, and $\mathrm{H} 6$ are used in current varieties. Hessian fly biotype L (predominant in collections from Illinois in 1987 and 1988) has overcome all these genes; biotype J infests all varieties except those using the H6 gene. Efforts to deploy other resistance factors in suitable varieties are ongoing. Residue destruction, crop rotation, and strict adherance to flyfree planting dates are especially important in the absence of effective resistance.

Physical factors, especially hairiness (pubescence) and glandular trichomes (hairs associated with secretory structures) interfere with aphids' abilities to feed. Chemical factors convey nonpreference and cause early mortality. In the case of the blue alfalfa aphid, tolerance is the main mechanism of resistance.

Hairiness and glandular trichomes interfere with feeding and egglaying. Saponins and other chemical factors may convey non-preference. Lignification (hardening) of stems may reduce egg-laying.

Tolerance is conveyed by heavy terminal growth and axillary branching. There are no truly resistant varieties available, although glandular trichomes may hinder early larval feeding. 
fields during most crop years. Problems also result from the fact that resistance genes may be difficult or impossible to locate in related wild species or may be difficult to transfer into a crop plant by conventional breeding techniques without altering important agronomic traits in the process.

Populations of insects can evolve in response to resistance mechanisms in plants and subsequently damage previously resistant varieties. Insect populations that have evolved to overcome the resistance mechanisms of plants are known as biotypes. Biotypes develop most frequently in response to plant chemical resistance factors that are controlled by a single gene (just as insecticide resistant popu- lations of pests evolve in response to compounds that interfere with specific metabolic steps). Physical factors, such as hairy or tough leaves, and resistance factors that are determined by multiple genes are less likely to favor the development of new pest biotypes.

Because pests can overcome resistance mechanisms, developing a resistant variety is not a onetime effort. For example, the Hessian fly (Figure 4) has been considered a minor pest of wheat in recent years because of the availability of resistant wheat varieties and because of the practice of delaying fall planting until after "fly-free dates" (see Wheat section in "Altering Planting and Harvesting

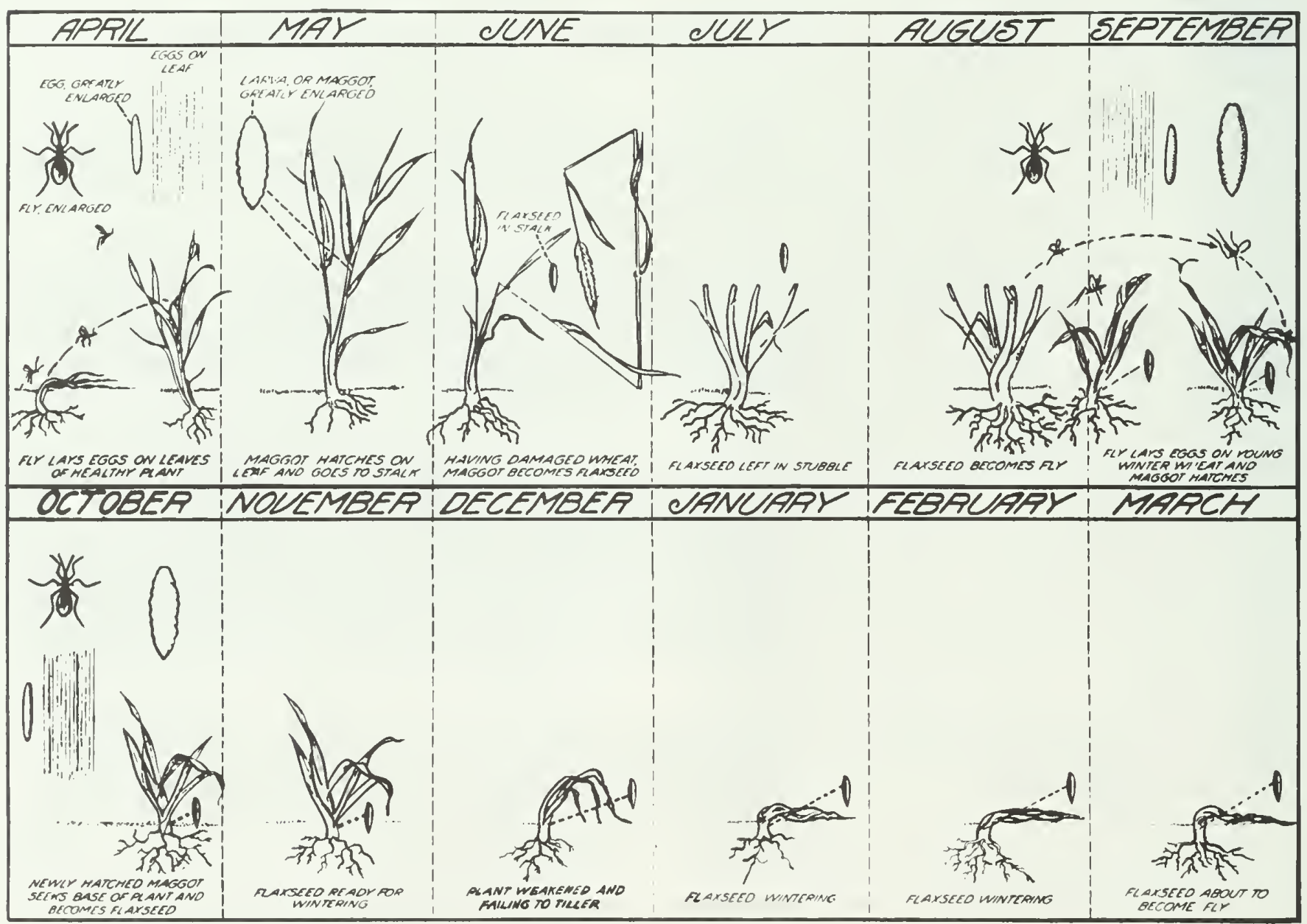

Figure 4. The Hessian fly. Hessian flies overwinter inside a puparium or "flaxseed" at the base of wheat plants. Flies emerge in the spring, mate, and deposit eggs on the leaves of winter or spring wheat. Larvae feed between the leaf sheath and stem, causing discoloration, abnormal tillering, yield reductions, and easier breakage and lodging of stems. Larvae pupate in the early summer, and another generation of adults emerges in late summer, mates, and deposits eggs on wheat if it is available. Destroying wheat stubble and volunteer wheat and delaying fall seeding until after "fly-free dates" disrupts this life cycle. (Illustration from USDA Farmers' Bulletin 1627.) 
Dates" on page 16). Although approximately 20 genes for Hessian fly resistance have been identified in wheat, only 5 have been deployed in public and private wheat varieties. Biotypes of the Hessian fly have developed in response to these resistance genes, and Hessian fly infestations can now be observed in all commercial varieties. Several years may elapse before breeding programs can incorporate additional resistance genes into new varieties with acceptable agronomic traits. Until new varieties with new resistance mechanisms are available, planting previously resistant varieties is recommended (see Table 5), but planting after established fly-free dates is especially important.

Table 4 lists the pests for which resistant varieties are available and the mechanisms of resistance. Table 5 lists some current resistant varieties.

New Technologies and Crop Resistance. New techniques in tissue culturing and genetic engineering offer new opportunities for deploying resistance genes into crop plants. (For background information on genetic engineering techniques, see Gasser \& Fraley 1989.) Although conventional crop breeding and variety development programs represent a form of "genetic engineering," recently developed techniques for the transfer of genes promise a revolution in applied genetics. The benefits of such techniques in the field of plant resistance include their relative speed and their specificity in comparison with traditional breeding programs; they also offer ways to transfer genes among separate species (transgenics).

The degree of genetic engineering that might be possible with new techniques includes such "minor" changes as more easily identifying specific resistance genes in a crop species and incorporating them into a current variety without compromising its desirable agronomic traits. If such an approach could be used to deploy already known genes for Hessian fly resistance into current varieties, the time required to develop new resistant varieties might be reduced substantially. Although incorporating foreign genes for resistance into the genetic code of an existing variety is possible, it is neither commonplace or simple.

More dramatic steps involving the transfer of a gene from one species to another are exemplified in the production of Bacillus thuringiensis (Bt) endotoxin in corn. Bt is a bacterium; different strains produce crystalline protein toxins that are poisonous to different groups or species of insects. Because these specific toxins are virtually nontoxic to vertebrates and most nontarget insects, they have been developed as safe and effective insecticides (see Alternatives in Insect Management: Microbial
Insecticides, Extension Circular 1295). Gene transfer techniques have been employed to produce corn plants that contain Bt toxins for caterpillar (European corn borer) control. Although the Bt gene that controls the production of the insecticidal protein has not been inserted directly into the corn genome, the toxin-controlling gene has been transferred to another bacterium that grows within corn tissues. Where this genetically altered bacterium has been used to inoculate corn seeds or plants, the corn plants subsequently contain sufficient toxin to protect the plant against corn borers.

Using $B t$ genes for plant resistance to insects opens new doors for advancements but also poses new problems. If corn varieties containing a $B t$ toxin are used widely, it seems likely that European corn borer populations will develop resistance to this very specific insecticidal compound. Although corn borers might eventually develop resistance to $B t$ as a result of its application to plant foliage, this outcome is less likely because only a small portion of the Midwest corn crop is treated for corn borer control. (Where the majority of a pest population is not exposed to an insecticide, the evolution of resistance to that insecticide is less likely.) In this instance, genetically engineering Btbased corn borer resistance into corn might speed the development of corn borer biotypes that cannot be controlled by Bt. These and other pitfalls associated with biotechnological advances in genetics do not preclude the beneficial application of these new technologies; they simply illustrate the need to consider a wide range of possible results.

\section{Altering Planting or Harvesting Dates}

The timing of planting or harvesting influences infestations of several pests. The degree to which planting or harvesting dates may be altered without adversely affecting crop performance, however, is constrained by many factors (for example, soil temperature early in the season, rainfall and soil moisture, tillage method, and crop variety). Altering planting dates may also involve trade-offs. among pests because changes designed to reduce damage from one pest may expose a crop to additional risk from a different pest. The most practical way to examine the effects of planting and harvesting dates is to discuss major crops individually.

\section{CORN}

Benefits of early planting. Planting corn as soon as possible after the risk of frost damage has declined is often advised for maximum yield. Planting early sometimes allows corn to escape serious damage from black cutworm. This benefit 
Table 5. Wheat and Alfalfa Varieties Marketed as Resistant to Specific Pests ${ }^{1}$

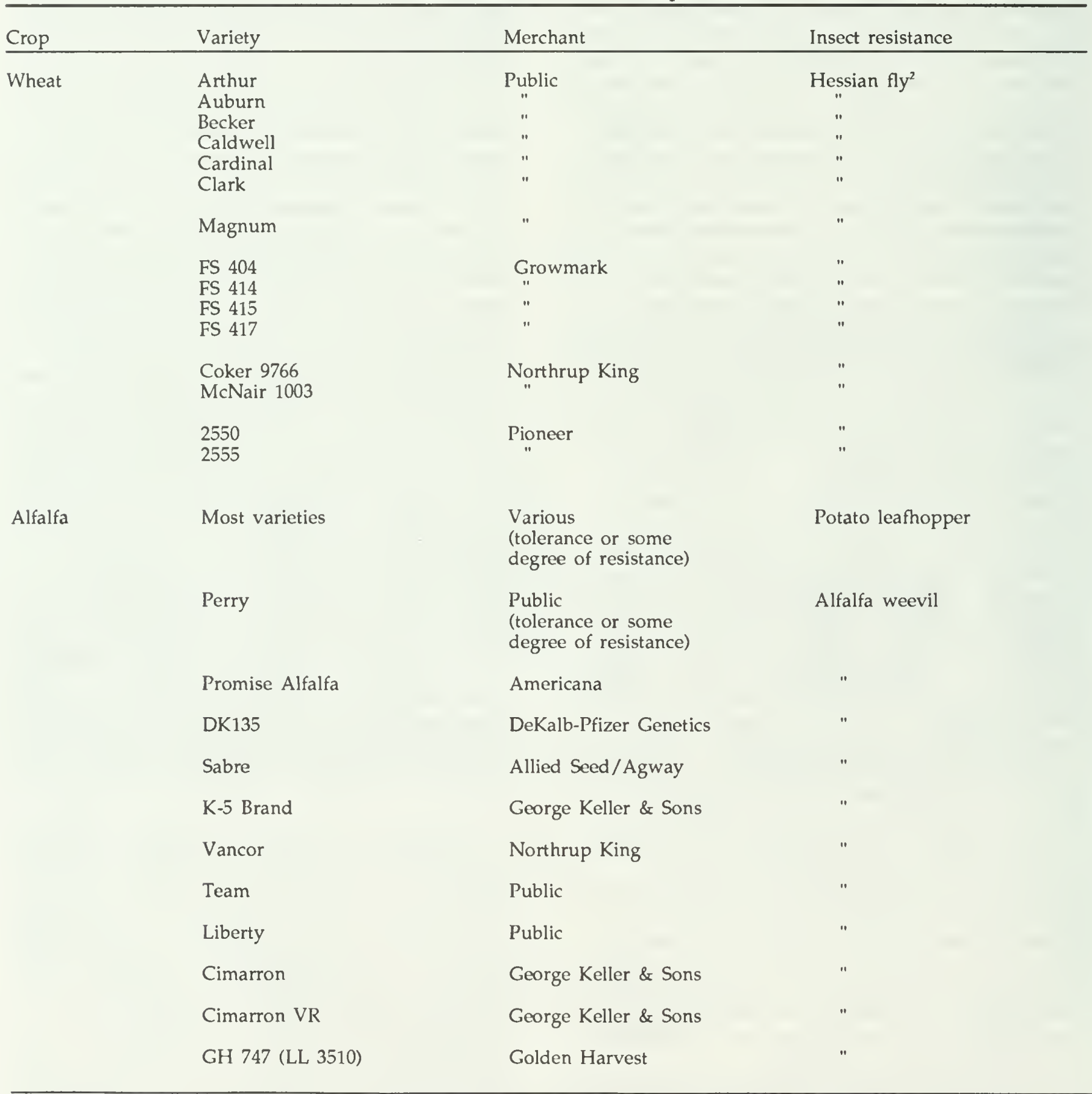

${ }^{1}$ Corn and soybean varieties with partial resistance to certain pests are not listed because differences in levels of resistance among commercial varieties are insufficient to form the basis for variety selection. This list may not include all resistant varieties available.

${ }^{2}$ Hessian fly biotype $L$ has overcome the resistance genes used in all the wheat varieties listed in this table. Using these varieties may reduce overall Hessian fly damage by preventing infestation by other biotypes, but no currently deployed resistance genes provide complete protection. 
comes about because weeds are removed by tillage before immigrating moths lay eggs in early fields, and corn may develop beyond a vulnerable growth stage before cutworm larvae reach a damaging stage in their development. The influence of planting date on black cutworm damage varies according to the dates on which black cutworm moths immigrate into an area from the south each spring. Earliest plantings in any area are usually least damaged by the season's second generation of European corn borer (Figure 5) because moths laying eggs for the second generation usually prefer the least-developed (latest planted) corn available. Tasseling and pollination sometimes occur in early plantings before corn leaf aphids or corn rootworm beetles become numerous, but this result is rarely important enough to influence planting time decisions.

Drawbacks of early planting. Damage caused by seedcorn beetles, seedcorn maggots, and wire- worms is greatest when seed germination is delayed in cold, wet soils. Damage from first-generation European corn borer is usually greatest in the most mature fields (those planted earliest) in a given area because moths laying eggs for the first generation prefer to deposit their eggs on whorlstage corn with an extended leaf height of at least 18 inches.

Benefits of late planting. In contrast to the results of planting early, planting later reduces the risk of damage caused by seedcorn beetles, seedcorn maggots, wireworms (somewhat), corn rootworm larvae, and first-generation European corn borer.

Drawbacks of late planting. Corn planted later than average is most likely to be damaged by black cutworm and second-generation European corn borer. The latest fields in an area are also most attractive to corn rootworm beetles. Although silk-feeding by these beetles is greatest in late

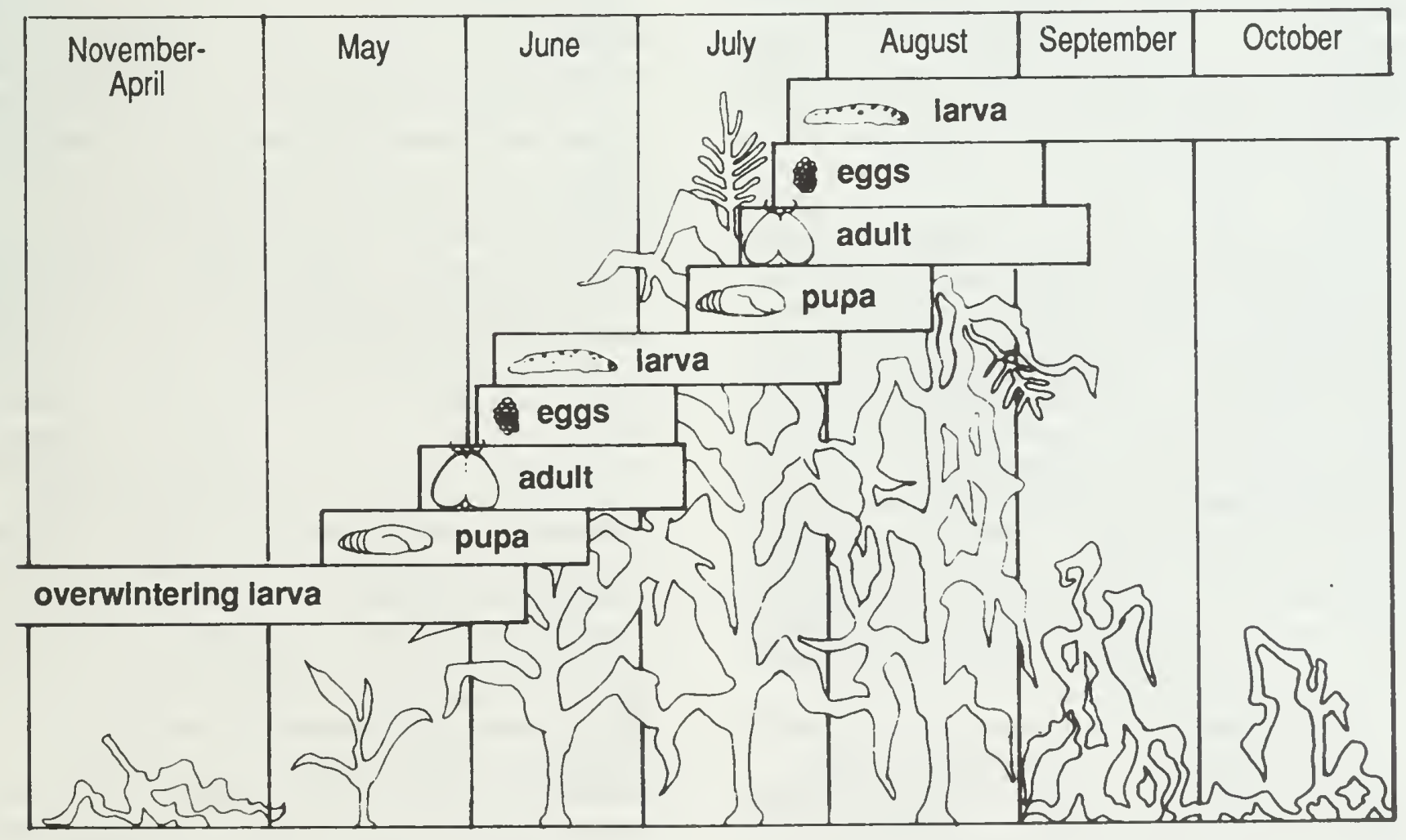

Figure 5. Life cycle of the European corn borer in Illinois. Larvae overwinter in cornstalks before pupating in May. Moths deposit eggs on whorl-stage corn, usually in June, and first-generation larvae develop within corn plants in June and July. These larvae give rise to a second moth flight that spans August. These moths deposit egg masses on leaves; larvae bore into stalks to feed and subsequently past the winter. (Illustration adapted from North Central Regional Publication No. 327, Iowa State University, Ames.) 
fields, damage rarely is severe enough to warrant treatment. But concentrations of beetles in late fields deposit large numbers of eggs in the soil, and corn planted in these fields the next year will likely be damaged by rootworm larvae. Maybe the greatest problem associated with late planting is that, under average rainfall and temperature patterns, delayed plantings do not yield as well as earlier plantings.

\section{SOYBEANS}

Planting dates have only minor impacts on insect and mite pests of soybeans. Later-than-normal plantings of soybeans sometimes escape damage from overwintered adult bean leaf beetles that feed on soybean seedlings. They also suffer less preemergence damage from seedcorn maggots and damping-off fungi that sometimes reduce crop stands in cool, wet soils. Later plantings may be more vulnerable to pod damage from late summer infestations of bean leaf beetles, stink bugs, and grasshoppers. Noting which pests are most common in early or late plantings of soybeans is appropriate, but because these pests rarely occur at levels requiring control, these observations do not justify any alteration in planting schedules.

\section{WHEAT}

Planting date is extremely important in the management of wheat insects, especially the Hessian fly (see Figure 4). Adult flies emerge from wheat stubble in the autumn and lay eggs in wheat seedlings. If wheat is seeded after the flies have emerged and died, the crop will be free of Hessian flies. Periods of Hessian fly activity have been recorded throughout Illinois and other wheat producing states, and "fly free" dates have been established. In Illinois, these dates range from September 17 near the Wisconsin border to October 12 at the southern tip of the state. NHE-152 (see References) lists fly free dates for Illinois counties. Seeding after these dates also avoids most virus-carrying aphid infestations.

When susceptible wheat varieties are seeded before fly-free dates or where volunteer wheat is available, infestations of Hessian fly become established in the fall. Larvae feed at the base of wheat plants and later pupate and overwinter. Adults emerge in the spring and lay eggs on winter or spring wheat where further damage is caused by larvae feeding between the leaf sheath and stem. This generation produces the adults that emerge from stubble to infest seedling wheat in the late summer or early fall.
When producers adhered to fly-free planting dates and used wheat varieties resistant to the Hessian fly, this pest caused only minor damage for many years. Perhaps because of declining awareness of the importance of the Hessian fly, in recent years many farmers have seeded wheat before fly-free dates, thereby risking the development of Hessian fly biotypes able to overcome the resistance mechanisms of varieties now in use. Wheat has also been used as a cover crop in set-aside acreage, and varieties susceptible to the Hessian fly often have been planted. As a result, the prevalence of Hessian fly has increased, and biotypes of this pest now infest previously resistant varieties (see Table 5). Considerable reductions in yield may result from Hessian fly infestations; these losses are often mistakenly attributed to disease or climatic factors. Adhering to fly-free planting dates and destroying volunteer wheat and wheat in set-aside acreage in late summer is required to manage this reemerging problem.

\section{ALFALFA}

Although planting date has little effect on insects in alfalfa, the alfalfa weevil and potato leafhopper can be managed in part by the timing of harvest. An early first cutting often reduces larval alfalfa weevil populations by exposing the larvae to sunlight, drier conditions, and increased predation. Early cuttings might be especially appropriate where insecticide applications would otherwise be needed and the planned harvest is only a few days away. Loss in yield due to early cutting might be offset by savings in insecticide costs. In addition, required intervals between insecticide application and harvest prohibit the use of certain insecticides in such a situation. Harvesting affects leafhopper populations in second and third cuttings by removing leafhopper eggs from the field along with the hay crop and by killing many immature leafhoppers. This contribution to leafhopper control does not provide the basis for setting a harvest schedule, but it does point out that infestations are reduced somewhat by harvesting. Because leafhoppers are mobile enough to reinfest fields after harvest and because alfalfa regrowth is especially susceptible to leafhpper damage, sampling to determine leafhopper densities is especially important a few days after cutting.

\section{Trap Crops}

Insect infestations can sometimes be manipulated by planting trap crops that attract pests away from the remainder of a field or area. Trap crops used in such a manner exploit the feeding or egg- 
laying preferences of individual species. These trap crops may be plant species that are especially attractive to the target pest; sometimes the usual crop species itself can be planted especially early or late to serve as a trap crop. After insects have been attracted to the trap crop, it may be treated with an insecticide or destroyed to control the pest population without treating an entire crop or field.

Plants that serve as trap crops have been identified for several pests. For example, blooming squash and pumpkins and late-planted corn attract corn rootworm beetles, drawing them away (somewhat) from mature corn in nearby fields. Snap beans (green beans) draw concentrations of bean leaf beetles from adjacent soybeans. In practice, however, the specifics of using these and other trap crops for controlling field crop insects are cumbersome or not well established.

Problems associated with the use of trap crops often involve issues of scale; attracting a high percentage of pests from vast acreages of corn, for example, would require numerous plantings of trap crops. Although densities of corn rootworm beetles are great in the trap crops listed above, beetle densities in surrounding fields are often influenced only slightly by any migration to small acreages of trap crops. Questions regarding how many strips or patches of trap crops and how far apart these crops could be planted remain unanswered. Consequently, land and other resources are seldom devoted to the production of trap crops. Using setaside acreage to grow strips or plots of trap crops might be practical if effective trap crops are identified.

\section{Reduced Tillage}

Reduced tillage systems are usually adopted to limit soil erosion, soil compaction, and the expenses associated with conventional tillage practices (mostly equipment, fuel, and labor). Tillage operations might be described as traditional or conventional tillage (moldboard plowing or chisel plowing and disking so that nearly all crop residue is incorporated), reduced tillage (at least 30 percent of the soil surface remains covered by crop residue), strip tillage and ridge tillage (approximately one-third of the soil surface is tilled for seeding the new crop; in ridge tillage the rows are raised), paraplowing (the soil and crop residue is lifted and loosened, but not inverted), or no-tilling (the new crop is seeded into narrow slits in the soil with no other disturbance of crop residues).

Tillage affects certain insect populations because it alters the soil and crop environment in which they develop. Tillage alters soil structure (porosity and bulk density, for example), displaces crop residues, and moves weed seeds, pathogens, and soil insects up or down in the soil profile. It also destroys weed seedlings, incorporates organic matter, and influences soil aeration, soil moisture, and soil temperature.

Reduced tillage contributes to cool soil temperatures (compared with conventionally tilled fields) early in the crop season because crop residues slow the warming process by insulating the soil surface and reflecting solar radiation. Under reduced tillage regimes, soil moisture is conserved somewhat because crop residues shade the soil surface. In general, no-till produces a more stable soil environment for pests and beneficial insects alike.

The insects most affected by changes in tillage practices are those that overwinter in the soil and become active during the early stages of crop growth. Soil- and litter-dwelling insects are affected more than the foliage-feeding insects. In most instances, a greater diversity of insects is present under reduced tillage, but this greater diversity does not always result in predictable increases or decreases in crop damage because pests and their natural enemies respond to tillage practices. Because generalizations about the effects of tillage provide little guidance for pest managers, pestspecific information is presented in Table 6. A few key observations from Table 6 are included here:

- Black cutworm moths (Figure 6), migrating into Illinois in the spring, prefer to lay their eggs where unincorporated crop residues and weeds (especially chickweed) are present. Although cutworm infestations in corn are not always greater in reduced tillage systems, reducing tillage may promote increased densities of weeds in fields before corn is planted. Consequently, the risk of cutworm infestations in corn is higher in reduced tillage programs when early spring weed growth attracts moths.

- The stalk borer, another caterpillar pest of corn, is more numerous in and adjacent to areas where grassy weeds remain standing from the previous season. In the spring this insect feeds within those grasses (where eggs were deposited the previous August) until it "outgrows" them or until these weeds are controlled by herbicide application. The stalk borer then moves into corn. Where reduced tillage systems allow the persistence of grassy weeds from one season to the next, the stalk borer can cause severe damage. 
- Slugs, not often considered economically important in Illinois field crops, are most common in reduced tillage or no-till fields in the southern one-third of the state. Crop residues on the soil surface provide a food source for slugs throughout the winter and early spring; these residues also help maintain cool, moist conditions that favor slug survival as these pests feed on seedling corn or soybeans.

- European corn borer infestations are influenced by tillage primarily on an area-wide basis. Corn borers overwinter as mature larvae in corn stalks; tillage actions that break up or bury corn stalks reduce overwintering survival. As the use of reduced tillage becomes more widespread in any given area, corn borer populations will likely increase (how great an increase is difficult to predict). Yet because corn borer moths are very mobile, flying from field to field during egglaying, the impacts of tillage are not confined to a single field, regardless of the tillage practice employed.

\section{Cover Crops}

Cover crops, usually grasses or legumes planted to provide ground cover during the period between primary crop seasons, provide a variety of benefits. They control soil erosion and contribute to soil tilth and organic matter; they may also reduce weed populations by shading or by production of allelopathic chemicals that inhibit the growth of certain other plant species. Legumes used as cover crops supply nitrogen. Typical cover crops include various clovers, hairy vetch, ryegrass, rye, wheat, and oats.

Cover crops are treated with herbicides or mechanically destroyed (by mowing or tillage) to allow the production of a subsequent crop. Where tillage is used, the cover crop may be completely incorporated by plowing or partially incorporated by disking. In no-till fields where herbicides or mowing is used to kill the cover crop, plant residues are left on the soil surface. The effects of cover crops on insect populations vary greatly among insects and according to the particular cover crop and its management (especially the time of seeding and the time and method of destruction).

In certain situations cover crops contribute to pest problems. Where corn is planted in no-till systems following grass cover crops (rye, wheat, etc.), the likelihood of armyworm infestations is greatly increased. Armyworm moths lay their eggs on the

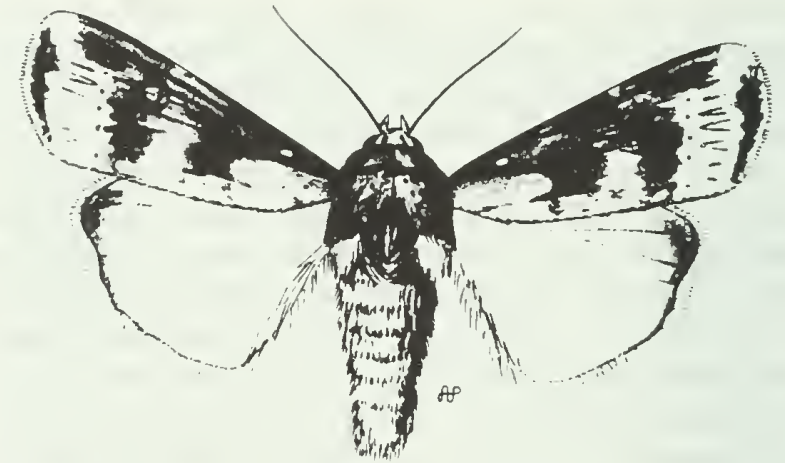

Figure 6. Black cutworm moth. Moths migrate into Illinois each spring, beginning in March. They deposit eggs in fields before corn is planted, choosing especially those fields with early season infestations of chickweed and other winter annuals. A statewide monitoring program indicates the timing and intensity of moth flights so that recommendations can pinpoint when and where to sample for cutworm presence and damage. (Illustration adapted from Practical Insect Pest Management, Vol. 2, by M.C. Wilson et al., Waveland Press, Prospect Heights, Illinois.)

grass cover crop, and larvae subsequently move from the cover crop to feed on corn. Slugs are also favored by the presence of cover crops (for the reasons listed in conjunction with reduced tillage), especially in southern portions of Illinois and during cool, wet springs.

In general, in fields where cover crops are grown, the number and diversity of insects is greater than usual (where no cover crop is used) when those fields are prepared for the establishment of a subsequent crop. This increase is especially apparent in hairy vetch. Although studies have shown that beneficial species and certain pests are more prevalent after cover crops, no consistent trends for increases or decreases in overall pest damage are apparent. When cover crops are used in lllinois, the "bottom line" advice concerning pest management is to be wary of armyworms and slugs and to monitor the subsequent crop closely for other pests and beneficial insects.

\section{Intercropping}

Intercropping, the practice of growing two or more crops simultaneously in the same field, can vary in form from mixed intercropping (no separate row arrangement) to row intercropping (alternating single rows) to strip cropping (alternating multiple rows). Mixed intercropping is practiced mostly in the tropics. Row intercropping, generally 


\section{Crop and}

insect

Effect

Notes

\section{CORN}

Corn rootworms

0

Wireworms

White grubs

Black cutworm

European corn borer

0 to +
0

0 to +++

Armyworm

Stalk borer

Corn earworm

Seedcorn maggot

Slugs
0 to +

0 to +++

$+$

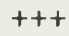

Adults lay eggs in late summer; subsequent tillage has little effect on the survival of eggs during most winters. In harsh winters with subnormal temperatures and subnormal snowfall, egg survival is somewhat greater in reduced tillage.

Increases in grassy weed populations, reduced soil disturbance, and delayed germination from cooler soil temperatures may aid wireworm build-up and damage.

Increases in grassy weed populations and reduced disturbance of soil favor survival of true white grubs.

Adult cutworm moths prefer to lay eggs in weedy fields and in fields with unincorporated crop residues. Increased populations of predators and parasitoids also develop, but an increase in cutworm damage often occurs anyway.

Reduced tillage favors greater survival of corn borers in crop residue, but effects in specific fields are minor because moths disperse from emergence sites to lay eggs in suitable fields throughout the local area. Where reduced tillage leads to delayed planting or slower germination (cooler soil temperatures), corn may be less susceptible to attack by first-generation corn borers and more susceptible to second-generation damage.

Ryegrass and other grass cover crops are especially attractive to egg-laying armyworm moths. In no-till systems where the grass cover is not plowed under, larvae move from the grass to feed on corn.

Overwintering survival is greatest in reduced tillage systems. In no-till fields, serious damage is most likely where grasses were present to attract egg-laying moths the previous August. If corn is no-tilled into soybean stubble where weeds were controlled during the previous year, stalk borers are not a problem.

If planting date or crop development is delayed in no-till fields, corn is usually more attractive to egg-laying moths. This is usually a very minor concern except for seedcorn producers.

Adult flies prefer to lay eggs where crop residue has been partially incorporated into soil. No-till corn stubble may be less attractive to egg-laying flies, but cooler, wetter soils shaded by crop residues slow germination and increase the period of vulnerability to seedcorn maggot injury.

Unincorporated crop residues and cooler, wetter conditions favor increases in slug populations and damage.

\section{SOYBEANS}

Bean leaf beetle

Grasshoppers
0

0 to +
Tillage has little effect on foliar feeding by bean leaf beetles.

Reducing tillage affects (favors) the survival of only those grasshopper species that lay eggs within fields. Those that lay eggs in weedy margins are not affected. 
Table 6. (cont.)

\begin{tabular}{|c|c|c|}
\hline $\begin{array}{l}\text { Crop and } \\
\text { insect }\end{array}$ & Effect & Notes \\
\hline $\begin{array}{l}\text { Soybeans (cont.) } \\
\text { Spider mites }\end{array}$ & - to 0 & $\begin{array}{l}\text { Where crop residues help to retard soil moisture loss, plants may be less } \\
\text { drought-stressed than in conventional tillage; reducing drought stress slows } \\
\text { mite outbreaks. }\end{array}$ \\
\hline Slugs & ++ & $\begin{array}{l}\text { Unincorporated crop residues and cooler, wetter conditions favor increases } \\
\text { in slug populations and damage. }\end{array}$ \\
\hline $\begin{array}{l}\text { WHEAT } \\
\text { Aphids }\end{array}$ & - to 0 & $\begin{array}{l}\text { Prior crop residues may decrease the attractiveness of new stands of wheat } \\
\text { to airborne aphids in the fall. (Seeding wheat after Hessian fly-free dates } \\
\text { avoids most fall infestations of aphids.) By spring, it is unlikely that prior } \\
\text { crop residues affect aphid invasion. }\end{array}$ \\
\hline Hessian fly & 0 to +++ & $\begin{array}{l}\text { Hessian fly populations carry over where wheat stubble is not tilled and } \\
\text { volunteer wheat is not controlled. Hessian flies from undisturbed stubble } \\
\text { move to new wheat that is planted before fly free dates. Hessian flies that } \\
\text { infest volunteer wheat in the late summer and early fall overwinter in the } \\
\text { volunteer plants and can move to additional fields in the spring (regardless } \\
\text { of those fields' fall planting dates). No-till seeding of wheat into other crop } \\
\text { residues poses no problem. }\end{array}$ \\
\hline $\begin{array}{l}\text { ALFALFA } \\
\text { Various pests }\end{array}$ & - to + & $\begin{array}{l}\text { Several insects damage new stands of alfalfa that are no-till seeded in the } \\
\text { fall. No-till seedings in the spring (into grasses) are less damaged by potato } \\
\text { leafhopper than conventional seedings are. }\end{array}$ \\
\hline $\begin{array}{l}\text { ALL CROPS } \\
\text { Beneficial insects such } \\
\text { as ground beetles, rove } \\
\text { beetles, parasitic wasps, } \\
\text { spiders, and ants }\end{array}$ & + to +++ & $\begin{array}{l}\text { In general, reducing tillage (reducing disturbance of residues and the top } \\
\text { few inches of the soil profile) favors the survival of ground beetles, rove } \\
\text { beetles, spiders, and ants; these groups of insects contain a number of } \\
\text { generalist predators that feed on other insects. Reducing tillage usually } \\
\text { allows some increase in weed presence, at least during some portions of the } \\
\text { season. The presence of flowering weeds provides nectar and pollen for } \\
\text { parasitic wasps. Because the conditions that favor survival and reproduction } \\
\text { of beneficial species also favor certain pests, increases in numbers of } \\
\text { predators and parasitoids may or may not lead to a reduction in overall } \\
\text { pest numbers or damage. }\end{array}$ \\
\hline
\end{tabular}

NOTE: $+++=$ substantial increase in pest or natural enemy population; $+=$ some increase; $0=$ no effect; $-=$ some decrease in pest or natural enemy population. 
too labor intensive for field crops, can be used even in the United States in the production of high value horticultural crops. For field crops in the Midwest, strip intercropping (four or more rows per strip) is the primary alternative to monocultures (fields of only one crop). Relay cropping, in which a second crop is seeded into an existing standing crop shortly before it is harvested (for example, seeding soybeans or a legume into standing wheat) might be considered as a form of intercropping, but relay crops share the same field for only a short time.

Why is intercropping important in pest management? Intercropping is one way to increase the diversity of plant species, herbivorous insects (planteaters), and insect predators and parasitoids in a field. Ecological research indicates that, in general, diverse ecosystems are more stable, in part because predators and parasitoids regulate pest populations and in part because certain pests are less able to locate host plants in mixed crop stands. Consequently, the increased diversity provided by intercropping is sometimes advocated as a way to minimize pest problems. Whether or not practical approaches to intercropping offer real benefits in Midwest field crops has not, however, been demonstrated.

A review of 150 studies of insect populations in agricultural systems with increased diversity found that 53 percent of 198 plant-eating species encountered in these studies were less abundant in more diversified systems (see Risch et al. 1983). Of the remaining species, 18 percent were more abundant in diversified systems, 9 percent were equally numerous in diversified and conventional systems, and 20 percent increased in some studies and decreased in others. Although the majority of the studies showed lower numbers of herbivorous insects (pests), only 19 of the 150 studies compared crop yields from the diversified and conventional systems. Yields were greater in the diversified system in 4 of the 19 studies, lower in the diversified system in 9 studies, and variable in the remaining 6 studies. Because crop yields (balanced with inputs), not the densities of pests or beneficial species, indicate the success of a crop production system, this review indicates that the benefits of diversification remain unclear. In sum, results from these studies suggest that much is to be learned in the application of ecological theories concerning crop diversity.

Although relevant data are available on very few mixed intercropping efforts in the Midwest, strip cropping can be practiced with little variation in typical production practices. For example, some farmers in northern Illinois have contour-planted alternating strips of corn and soybeans to allow crop rotation without excessive soil erosion on rolling hills. While this application of strip cropping offers clear benefits, it does complicate the selection and use of herbicides.

Recent studies conducted in Illinois (see Oloumi-Sadeghi et al. 1989) indicate that the presence of grassy weeds in alfalfa is associated with reduced infestations of potato leafhoppers. (The moderate levels of grassy weeds in this research did not reduce alfalfa yield.) These results suggest direct benefits from at least minor reductions in weed control; intercropping grasses and alfalfa could also discourage leafhopper outbreaks where hay quality concerns and market demands can be met by such a blend of forages.

Research conducted in Ontario, Canada, has shown reductions in European corn borer infestations in corn where red clover was interseeded within 10 days of corn planting (see Lambert et al. 1987). Corn yields were not reduced in the mixedcrop fields. Although this approach to intercropping complicated weed control practices, it also improved soil fertility.

\section{CONTROLLING PEST INFESTATIONS}

Although rotating crops, using resistant varieties, and altering planting or harvesting dates minimize problems caused by certain key insects, pest outbreaks still occur in some fields. Responding to such outbreaks with a minimum use of broadspectrum insecticides requires (1) regular monitoring of crops to identify and quantify populations of pests and beneficial insects; (2) use of established thresholds that indicate the density of a pest that can be tolerated without economic damage; and (3) selection of the least toxic method that will effectively and economically reduce pest densities.

\section{Monitoring Pest Populations}

Monitoring or "scouting" fields for pest infestations involves a wide range of pest detection practices that differ for specific crops and pests. Sampling methods include the use of baited traps, a sweep net or ground cloth, and visual inspection of plant surfaces. Resource materials that describe pest scouting procedures for Illinois field crops include Chapter 1 of the 1991 Illinois Pest Control Handbook, "Insect Pest Management for Field and Forage Crops"; the Field Crop Scouting Manual; and the Pest Management \& Crop Development Bulletin (a newsletter produced weekly from April through 
August). See the References section for information on these resources.

\section{Thresholds for Control}

Common insect pests of any given crop usually occur at some level in nearly all fields where that crop is grown. Yet in most fields these pests do not cause enough damage to warrant control. Determining the need to control a pest infestation usually involves comparing observed densities with estimates of economic thresholds for that pest. An economic threshold is the density of a pest that will, if uncontrolled, cause enough crop loss to offset the dollar costs (insecticide and application) of control.

Economic thresholds have been established or estimated for many insect pests of Illinois field crops. In some instances those thresholds are "dynamic," incorporating estimates of crop yield, crop value, and specific control costs. For other pests, control decisions are guided by "static" thresholds (constant over a range of circumstances) because knowledge of the pest's impact on the crop is insufficient to allow more precise calculations. The references cited above present information on thresholds for most field crop insects.

Because Illinois field crops are less valuable on a per-acre basis than horticultural crops such as fruits and vegetables, and because grains, soybeans, and forages are not subject to the strict cosmetic standards applied to fruits and vegetables, many pest infestations do not warrant control. Estimates of relatively infrequent use of insecticides on Illinois field crops (Pike et al. 1990) reflect this situation. Even though using economic thresholds does not result in intensive application of insecticides on Midwest field crops, producers should note that such thresholds do not incorporate environmental considerations (for example, possible wildlife poisonings or reductions in populations of beneficial insects) or concerns about such hard-to-predict events as the development of insecticide resistance or enhanced degradation that may be favored by frequent use of insecticides. Consequently, when insect infestations exceed established thresholds only slightly, producers may be wise to consider these long-term impacts and refrain from using pesticides in at least some situations.

\section{Selecting Alternative and Conventional Control Methods}

Four other circulars in the Alternatives in Insect Management series (Extension Circulars 1295-1298; see References) present alternative approaches to insect management in general. Although the use of alternatives in field crop insect management is summarized briefly below, readers are encouraged to refer to these publications for additional details.

The microbial insecticides, those containing or derived from insect pathogens such as viruses, bacteria, fungi, protozoans, or nematodes, are attractive alternatives to conventional insecticides because each is somewhat selective (killing a comparatively narrow range of insects) and all are very low in toxicity to humans and other vertebrate animals. Of the microbial insecticides, preparations of Bacillus thuringiensis kurstaki, or simply $B t$, are most widely used in field crops. Products such as Dipel, Javelin, and others (see Alternatives in Insect Management: Microbial Insecticides, Extension Circular 1295) kill caterpillars that eat the Bt spores or toxin applied to plant foliage. These $B t$ products kill only caterpillars; they do not control other types of pests. Because $B t$ must be ingested to be effective, the caterpillar pests that do not feed on treated surfaces of plants are difficult to control by normal applications of Bt. Pests that are effectively controlled by $B t$ include European corn borer in corn (first-generation control is better than second-generation control), green cloverworm and loopers in soybeans, and alfalfa caterpillar. Where liquid formulations of $B t$ are applied as sprays to control these insects, using ground sprayers maximizes spray coverage and improves control. Several other caterpillars such as cutworms, stalk borer, and fall armyworm are not controlled by conventional applications of $B t$.

Currently, no other microbial insecticides are suited for use against insect pests of lllinois field crops. Efforts to develop preparations of the soil fungus Beauveria bassiana and the insect-pathogenic nematode Steinernema feltiae for the control of numerous soil insects, including corn rootworms, are ongoing, but no products are yet available for use in Midwest field crops.

The botanical insecticides, plant-derived compounds such as pyrethrum (and pyrethrins), rotenone, sabadilla, ryania, limonene, and linalool, are of interest as alternatives to synthetic insecticides primarily because they break down rapidly in the environment, thereby posing little or no threat as long-term environmental contaminants. Although there are exceptions, most botanical insecticides are lower in toxicity than commonly used synthetic insecticides (see Alternatives in Insect Management: Botanical Insecticides and Insecticidal Soaps, Extension Circular 1296).

Although botanical insecticides are used to control pests of livestock, pets, and garden plants, their use in field crops is rare, in part because of 
limited supplies and high costs. Nonetheless, a few specific products are used in organic production systems. Ryania has been used to provide some control of European corn borer ( $B t$ treatments are cheaper and more effective), and rotenone controls leaf-feeding beetles in a number of crops. Pyrethrins can be used for the control of a broad range of insects, but their rapid breakdown (within a few hours) usually renders them ineffective in field crop applications.

Insect attractants and traps are widely used in monitoring field crop pests; however, their use for direct control (mass trapping, mating disruption, or with toxic baits) is less common. Hundreds of attractant-baited traps are used to detect the spring immigration of black cutworm moths into Illinois each year so that producers throughout the state know when to monitor fields for this pest. (Information provided by this trapping program is distributed weekly in the Pest Management \& Crop Production Bulletin; see References.) Traps can also be used to determine the seasonal timing and relative density of flights of the European corn borer moth, corn rootworm beetle, and corn earworm moth. For extensive details on the use of attractants and traps in insect management, see Alternatives in Insect Management: Insect Attractants and Traps, Extension Circular 1297.

Research is ongoing to develop an attractantinsecticide combination for use as a poison bait for the control of corn rootworm beetles. The potential benefits of such a product might include its specificity (killing only the species attracted to the bait) and its limited threat to environmental quality (much less insecticide is needed when an attractant effectively draws the pest to the poison).

Beneficial insects and mites include the predators and parasitoids that attack pests. Although commercial distributors sell a wide range of insect predators and parasitoids, few (if any) species are likely to provide meaningful levels of control of field crop pests. Any purchase and release of beneficial insects has to be considered experimental; existing data are inadequate for developing concrete recommendations on release rates for parasitoids and predators.

For producers interested in using beneficial insects despite the uncertainties, two "best choices" exist. Larvae of the green lacewing Chrysoperla carnea prey on aphids, caterpillar eggs, mites, and a range of soft-bodied insects. Where this insect has been released at rates of 50,000 to 100,000 eggs per acre in each of two or three weekly releases, it has provided control of certain caterpillar and aphid pests in corn and cotton. Tiny parasitic wasps in the genus Trichogramma attack other insects' eggs and have been used experimentally to reduce European corn borer infestations in corn. For first-generation control, three weekly releases of 100,000 Trichogramma per acre should begin as soon as corn borer moths are captured in light or pheromone traps. Control of second-generation corn borers may require higher release rates and/ or a longer release period because corn borer egglaying usually extends over a longer period. Although Trichogramma pretiosum is sold for use in field crops, Trichogramma nubilale (not available commercially) is likely to be more effective against European corn borer.

Where short-term reduction of a pest population is needed, it is important to note that predators and parasitoids must be released in extremely high numbers to be effective. Although high costs and limited supplies of laboratory-reared predators and parasitoids make high release rates impractical in many situations, purchasing and releasing small numbers of common beneficial insects is very unlikely to provide any meaningful impact on pest infestations. Because many questions about release rates, the suitability of laboratory-reared predators and parasitoids, and the degree of control obtainable by releasing natural enemies still remain unanswered, practical approaches to maximizing the effects of natural enemies in field crops often concentrate on conserving existing populations instead of buying and releasing beneficial insects. Although no single step provides a simple way to conserve the broad range of beneficial insects that attack the many pests of field crops, a few generalizations apply.

- Recognizing beneficial species and pests. The identification of pests and beneficial species is the first step in determining whether or not control is necessary. Alternatives in Insect Management: Beneficial Insects and Mites, Extension Circular 1298, and picture sheets available from the University of Illinois Office of Agricultural Entomology provide illustrations of many pests and beneficial species.

- Minimizing insecticide applications. Most insecticides kill predators and parasitoids along with pests. As a result, few beneficial species survive in numbers sufficient to have any impact on pest infestations that escape insecticide applications or develop shortly after insecticide treatments. The use of insecticides can be reduced by rotating crops, selecting appropriate planting dates, and planting resistant crop varie- 
ties. Where pest infestations do develop, treating only where infestations exceed established thresholds also avoids unnecessary use of insecticides.

- Using selective insecticides or applying insecticides in a selective manner. A selective insecticide is more toxic to certain insects than to others. Although the ideal insecticide might be one that kills only a single target species, few insecticides offer this degree of selectivity. Nonetheless, Bt, as mentioned above, is toxic only to caterpillars and is an effective option for European corn borer control in corn. Limiting insecticide applications to areas of a field where infestations exceed threshold levels might be viewed as a selective method of application.

- Maintaining ground covers, crop residues, and standing crops. Many natural enemies of pests require the protection offered by vegetation to overwinter and survive. Cover crops supply prey and sometimes pollen and nectar (important foods for the adults of some predators and parasitoids), and as discussed earlier, most studies indicate that natural enemies are more prevalent in no-till and reduced tillage systems than in conventionally tilled fields. Beneficial species also move into crops from woodlots, windbreaks, fencerows, and unmowed grassy ditchbanks and waterways. Preserving these uncultivated areas contributes to the natural biological control of pests. Harvesting alternate strips of alfalfa on a schedule that allows several days of regrowth before the remaining strips are cut helps to keep natural enemies in alfalfa fields. (They must emigrate from the field or perish when the entire crop is cut.) Increasing crop diversity also influences natural enemy populations, as discussed earlier in conjunction with intercropping and strip cropping.

- Providing pollen or nectar sources or artificial foods. Adults of some parasitic wasps and certain predators feed on pollen and nectar. Plants with very small flowers (such as some clovers, Queen Anne's lace, and other plants in the family Umbelliferae) serve as good nectar sources for these beneficial insects. The presence of flowering weeds in and around fields may also favor natural enemies. Artificial food supplements containing yeast, whey proteins, and sugars can be used to attract or concentrate adult lace-wings, lady beetles, and syrphid flies. Wheast, BugPro, and Bug Chow are examples of such food supplements available for purchase.

Practices that favor natural enemies must be judged according to their impact on pest populations and crop performance as well as their effect on natural enemies. Such practices may or may not lessen overall pest loads or result in acceptable yields. Readers are reminded that reduced tillage and the use of cover crops provide both positive and negative consequences. The "bottom line" is that certain steps are always justified (identifying pests and beneficial species, minimizing insecticide use, and using selective insecticides); the value of other steps is more difficult to assess.

Using Conventional Insecticides. Where alternatives to conventional insecticides do not solve insect pest problems, several choices still remain. In situations where crop losses are likely to be minor (pest infestations exceed thresholds only slightly), choosing to do nothing and to accept the loss is a viable alternative. Organic producers may face this option frequently. To minimize such problems as pesticide drift and the unnecessary treatment of uninfested acreage, applicators can use ground application equipment and/or "spot-treat" only the infested portions of fields.

Choosing the "best" conventional insecticide involves evaluating criteria that are too extensive to discuss in detail in this publication. Acute toxicity to humans and wildlife, water solubility, and environmental persistence are three of the important characteristics that should be considered; effectiveness against target pests is another. Although no reference identifies the single best insecticide for a given pest control problem, the annually revised Illinois Pest Control Handbook presents information on pesticide toxicities. Publications by Bicki (1988) and Becker et al. (1989) provide additional information on pesticides in the environment.

\section{SUMMARY}

The majority of the field crop acreage in Illinois is not treated with an insecticide on an annual basis. Nevertheless, opportunities exist to reduce the use of broad-spectrum insecticides without reducing crop yields. Rotating crops for corn rootworm control and following Hessian fly-free seeding dates for winter wheat are two examples of effective, nonchemical pest management practices. Practices such as the use of reduced tillage and cover crops are likely to produce mixed results in terms of pest management; populations of some pests will increase while others decrease. Regard- 
less of the effects of crop production practices, monitoring pest populations and treating only when necessary still represent important steps in optimizing the use of insecticides. Where pest problems occur, pesticides such as $B t$ offer clear advantages to the environment and to human health. Where no "alternative" methods of pest management exist, procedures as simple as spot spraying offer obvious advantages over spraying entire fields when only small portions are infested. Overall, using the least toxic and least disruptive approaches to pest management can help to insure a positive future for Midwest agriculture.

\section{ACKNOWLEDGMENTS}

Don Graffis (University of Illinois), Paige Taylor (USDA, West Lafayette, Indiana), and Marcos Kogan (Illinois Natural History Survey) contributed information for this publication. The authors thank Audrey Hodgins of the Illinois Natural History Survey for editorial contributions.

Funding to develop this publication was provided in part by a grant from the Illinois Department of Energy and Natural Resources (ENR Project No. IP13) and by the Cooperative Extension Service, University of Illinois.

\section{REFERENCES}

\section{Available from Other University of Illinois} Sources:

Alternatives in Insect Management: Beneficial Insects and Mites. 1990. T. Henn \& R. Weinzierl. Extension Circular C 1298.

Alternatives in Insect Management: Botanical Insecticides and Insecticidal Soaps. 1989. T. Henn \& R. Weinzierl. Extension Circular C 1296.

Alternatives in Insect Management: Insect Attractants and Traps. 1990. R. Weinzierl, T. Henn, R. Randall, P. Nixon, \& M. Gray. Extension Circular 1297.

Alternatives in Insect Management: Microbial Insecticides. 1989. R. Weinzierl \& T. Henn. Extension Circular 1295.

These and forthcoming publications in the Alternatives in Insect Management Series are available from Communications Services,
Office of Agricultural Communications and Education, University of Illinois, 69 Mumford Hall, 1301 West Gregory Drive, Urbana, Illinois 61801.

Field Crop Scouting Manual. 1990. W.S. Curran, M.E. Gray, M.C. Shurtleff, D.E. Kuhlman, A.M. Carrick, R.W. Koethe, \& N.N. Troxclair. Publication No. X880a available from the University of Illinois Vocational Agriculture Service, 1401 South Maryland Drive, Urbana, IL 61801.

Pest Management \& Crop Development Bulletin. A weekly newsletter (25 issues per season) that provides timely information and field updates on insect, weed and disease management, soil fertility, and crop development. Subscriptions are available from the University of Illinois Ag Newsletter Service, 116 Mumford Hall, 1301 West Gregory Drive, Urbana, IL 61801.

NHE-152, Hessian Fly. Fact sheet available from the University of Illinois Office of Agricultural Entomology, 172 Natural Resources Building, 607 East Peabody Drive, Champaign, IL 61820.

1991 Illinois Pest Control Handbook (IPC-91). Available from Communications Services, Office of Agricultural Communications and Education, University of Illinois, 69 Mumford Hall, 1301 West Gregory Drive, Urbana, lllinois 61801.

Other Cited References and Additional Resources

Scientific journals (title followed by volume: pages) are accessible primarily through university libraries. Most book titles listed below are available by special order through major bookstores.

Becker, R.L., D. Herzfeld, K.R. Ostlie, \& E.J. Stamm-Katovich. 1989. Pesticides: Surface runoff, leaching, and exposure concerns. AG-BU-3911, Minnesota Extension Service, University of Minnesota, St. Paul.

Bicki, T.J. 1988. Pesticides and Groundwater. Land and Water No. 12.

Gasser, C.S., \& R.T. Fraley. 1989. Genetically engineering plants for crop improvement. Science 244: 1293-1299.

Lambert, J.D.H., J.T. Arneson, A. Serratos, B.J.R. Philogene, \& M.A. Faris. 1987. Role of intercropped red clover in inhibiting European corn borer 
(Lepidoptera: Pyralidae) damage to corn in eastern Ontario. Journal of Economic Entomology 80: 1192-1196.

Metcalf, R.L. \& W.H. Luckmann (eds.). 1982. Introduction to Insect Pest Management (2nd ed.). John Wiley \& Sons, New York.

Oloumi-Sadeghi, H., L.R. Zavaleta, G. Kapusta, W.O. Lamp, \& E.J. Armbrust. 1989. Effects of potato leafhopper (Homoptera: Cicadellidae) on alfalfa yield and quality. Journal of Economic Entomology 82: 923-931.

Pedigo, L.D. 1989. Entomology and Pest Management. Macmillan Publishing Co., Indianapolis, Indiana.
Pike, D.R., E.L. Knake, D.E. Kuhlman, M.D. McGlamery, \& N.R. Pataky. 1990. Pesticide use in Illinois: Results of a 1988 Survey of Major Crops. Extension Circular 1301. Order from Communications Services, Office of Agricultural Communications and Education, 69 Mumford Hall, 1301 West Gregory, Urbana, Illinois 61801 . University of Illinois at Urbana-Champaign.

Risch, S.J., D. Andow, \& M.A. Altieri. 1983. Agroecosystem diversity and pest control: data, tentative conclusions, and new research directions. Environmental Entomology 12: 625-629.

The information in this circular is provided for educational purposes only. Trade names of insecticides have been used for clarity, but reference to trade names does not imply endorsement by the University of Illinois; discrimination is not intended against any product. The reader is urged to exercise caution in making purchases or evaluating product information.

Label registrations can change at any time. The user is encouraged to read carefully the entire, most recent label and follow all directions and restrictions. Purchase only enough pesticide for the current growing season. 


$\begin{array}{ll}\text { Illinois } & \begin{array}{l}\text { Helping You } \\ \text { Put Knowledge to Work }\end{array} \\ \begin{array}{l}\text { Cooperative } \\ \text { Extension } \\ \text { Service }\end{array} & \begin{array}{l}\text { Ut Urbana-Champaign } \\ \text { College of Agriculture }\end{array}\end{array}$

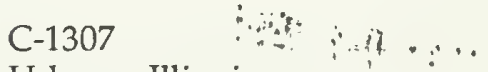

Urbana, Illinois

TM - 6M - February 1991

Issued in furtherance of Cooperative Extension Work, Acts of May 8 and June 30, 1914, in cooperation with the U.S. Department of Agriculture. DONALD L. UCHTMANN, Director, Cooperative Extension Service, University of Illinoïs at.Ehrbana-Champaign. The Illinois Cooperative Extension Service provides equal opportunities in programs and employment. : $: 4$ 


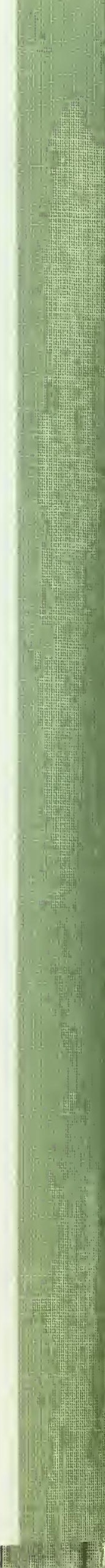


 \\ UNIVERSITY OF ILLINOIS-URBANA

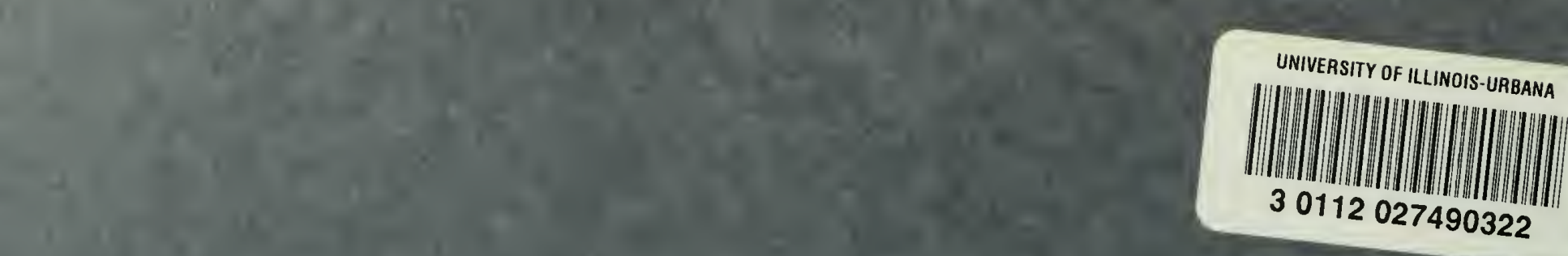

